\title{
Evaluation of some wheat genotypes for tolerance to water deficit based on some agronomic, yield components and chemical traits.
}

\author{
EL Shal M. H. ${ }^{1}$, S.A. Arab ${ }^{1}$ and S.T.Eissa ${ }^{2}$ \\ ${ }^{1}$ National Gene Bank, Agricultural Research Center, Giza, Egypt, ${ }^{2}$ Wheat Research Department, Field Crop Research \\ Institute, Agricultural Research Center (ARC), Giza, Egypt
}

Received on: $20-3-2021$

Accepted on: 8-5-2021

\begin{abstract}
Fifteen wheat genotypes were evaluated under normal and water deficit irrigation by using different statistical procedures. The resulted showed that the phenotypic coefficients of variation were high for ash percentage, plant height, spike length and grain yield per plot under normal and water stress irrigation. Genotypic coefficients of variation were high for plant height, spike length and grain yield per plot under normal and water irrig ation. positive correlation coefficients were observed under normal and water stress irrigation as follows; position correlation coefficient among number of spikes $/ \mathrm{m}^{2}$ each of 100 - kernel weight, number of kernels/spike each of 100- kernel weight, number of kernels/spike each of grain weight/plot, 100- kernel weight with grain weight/plot and the last positive correlation coefficient was between Protein percentage with Ash percentage under normal and water deficit irrigation. The direct contribution of 100- kernel weight to grain yield was highest under normal irrig ation followed by number of kernels per spike at water deficit. 100- Kernel weight had the highest indirect effect an appreciable indirect effect via a number of kernels per spike under normal irrig ation followed by a number of spikes per $\mathrm{m}^{2}$ under normal irrigation. Number of kernels per spike also had an appreciable indirect effect via a number of spikes per $\mathrm{m}^{2}$ at water stress followed by 100 - kernel weight of water deficit. The results of the principal component analysis showed that the first two components explained (40.62 and $18.20 \%)$ and (32.42\% and $22.41 \%)$ under normal and water deficit irrigation respectively, of the total variation.
\end{abstract}

KEYWORDS: wheat-normal irrigated-w ater stress-correlation-path coefficient-Principal component

\section{INTRODUCTION}

Wheat is an important cereal crop used as major human consumable commodity in most areas of the world. Differential characterization between Egyptian old varieties, genetic resources according to geographical distribution, for example old bread wheat represent an important genetic resource that can be used to improve modern varieties by introducing new alleles or combinations of genes. The old varieties may include genetic sources for biotic and abiotic stress resistance quality, grain yield especially in environments not tested in major breeding programs.

Water deficit is main abiotic constraint on cereal yield, especially in countries with low rainfall rates, therefore researchers are working to develop varieties adapted to water deficit conditions and keeping reasonable high yield. For successful breeding program basic information about the breeding material must be available to the breeders. Firstly, there must be significant variability in genotypic responses to water stress and second, this variation must be genetically controlled.
Thus, an understanding of the knowledge of these two components about the breeding material under consideration is necessary (Mitra, 2001).

The correlation coefficient is an important statistical method, which help wheat breeders in selection for high yield. Correlation among different characteristics is generally due to the presence of linkage and pleotropic effect of different genes. Environment plays an important role in the development of phenotype correlation (Ali et al., 2009).

As such, heritability, and both phenotypic and genotypic coefficients of variability can be used to identify key traits to improve drought tolerance (Sohail et al., 2018).

Genetic variation and heritability estimates in early generations are important in identifying superior families that can be targeted for genetic advancement (Kwame et al., 2019).

Path coefficients have been used to develop selection criteria for complex traits in several crop species of economic importance such as wheat Aydin et al., 


\section{EL Shal M.H et al., 2021}

(2010) and is used to determine the amount of direct and indirect effects of the causal components. Path coefficient analysis revealed that grain yield of triticale depended on the effect of four yield components (number of spike per plant, grains number per spike and thousand grain weight was positive while protein was negative) whereas grain yield of bread and durum wheat was mainly due to plant height, length of spike, a protein, in addition to these, spike weight for durum wheat. Even though the effect of spike weight was positive, plant height and protein had a negative effect on the grain yield of durum wheat (Gulmezoglu et al., 2010).

Since coefficients of correlation may singly not provide thorough information about the relations of different traits and given the various advantages of multivariate statistical analyses for deep understanding of data structure and factor analysis Naghavi and Khalili (2017). The objectives of this study were:

- Study the relationship among morphology, chemical characters and yield components.

- Detect the direct and indirect effective traits on grain yield under normal irrigation and water deficit conditions to determine water deficit tolerance character.

- Assessing the usefulness of applying principal component analysis to research on wheat genotypes.

\section{MATERIALS AND METHODS}

This experiment was carried out at Sids Agricultural Research Station in two successful seasons, 2017/2018 and 2018/2019. Thirteen wheat landraces as well as two commercial cultivars regenerated and evaluated for tolerance and decrease water (Table 1). These landraces collected by National Gene Bank (NGB) team from diverse areas in Egypt. The experiment is grown in a randomized complete block design with three replications. The first experiment normally irrigated (five times) and the second experiment irrigated only once after 20 days from the sowing date. Each plot consisted of six rows; each row was 3 meters long and $30 \mathrm{~cm}$ apart. Plants within rows were $20 \mathrm{~cm}$ distant.

1. Days to heading $(\mathrm{DH})$.

2. Plant height $(\mathrm{PH})$.

3. Number of spikes $/ \mathrm{m} 2$ (No.S $/ \mathrm{m} 2)$.

4. 100- Kernel weight (100-KW).

5. Days to maturity (DM).

6. Spike length (SL).

7. Number of kernels /spike (No.K/S).

8. Grain weight / plot (GW/P).

\subsection{Estimation of protein, carbohydrate and ash} percentages: -

Total seeds storage protein percentage, carbohydrate percentage and ash percentage were determined by near infra analyzer (NIR), according to Zhao et al., (2004). The protein percentage content, carbohydrate and ash percentage contents, then expressed in $\mathrm{g} / 100 \mathrm{~g}$ of the seeds.

Table 1. Barcoding number and sources of wheat genotypes.

\begin{tabular}{cccccc}
\hline No & Barcoding number & Source & No. & Barcoding number & Source \\
\hline 1 & 112866 & Egypt & 9 & 112889 & Egypt \\
2 & 112868 & Egypt & 10 & 112891 & Egypt \\
3 & 112869 & Egypt & 11 & 112893 & Egypt \\
4 & 112871 & Egypt & 12 & 112895 & Egypt \\
5 & 112872 & Egypt & 13 & 112896 & Egypt \\
6 & 112874 & Egypt & 14 & Sids 13 & Cultivar \\
7 & 112875 & Egypt & 15 & Yacora & \\
8 & 112876 & Egypt & & &
\end{tabular}

\subsection{Statistical analysis}

The genotypic and phenotypic variances were calculated from the partitioning mean squares expectation; where, $g$ and $r$ are a number of genotypes and replic ations, respectively. Broad sense heritability $\left(\mathrm{H}^{2}\right)$ was estimated from the formula of (Roy 2000 and Abraha et al. 2017) as follows;

Genotypic variance: $\mathrm{O}^{2} \mathrm{~g}=\frac{\mathrm{M} 3-\mathrm{M} 2}{\mathrm{ry}}$; Genotype- year variance: $\widehat{O}^{2} \mathrm{gy}=\frac{\mathrm{M} 2-\mathrm{M} 1}{\mathrm{r}}$

Error: $\mathrm{O}^{2} \mathrm{e}=\mathrm{M} 1$;

Phenotypic variance (overall variance):

$\mathrm{O}^{2} \mathrm{ph}=\mathrm{O}^{2} \mathrm{~g}+\frac{\mathrm{O}^{2} \mathrm{gy}}{\mathrm{y}}+\frac{\mathrm{O}^{2} \mathrm{e}}{\text { gry }}$

Broad sense heritability: $h^{2}$ b.s. $=\frac{\hat{O}^{2} \mathrm{~g}}{\widehat{O}^{2}} \mathrm{ph}$ 


\section{Scientific Journal of Agricultural Sciences 3 (1): 92-100, 2021}

Coefficient of genetic variation $(\mathrm{CGV})=$

$$
\text { (genetic variance) }^{1 / 2} \times 100
$$

Overall mean

Coefficient of phenotypic variation $(\mathrm{PGV})=$ $\frac{\text { (phenotypic variance) }^{1 / 2}}{\text { On }} \times 100$

Overall mean

The correlation coefficient calculated according to the method outlined by (Snedcore and Cochran 1967). The simple phenotypic correlations were made among morphological, three chemical traits and yield component characters.

Path coefficient analysis performed to divide the correlation coefficient between grain yield and the agronomic traits (riy) into direct (piy) and indirect effects (riy piy) according to the following equation: $\mathrm{r} 1 y=\mathrm{p} l y+\mathrm{ri} y$ piy

The technique allowed the evaluation of the direct causal effect or path coefficient (piy) of a cause (i) on an effect (y i.e. grain yield) and indirect effect of that cause through another causal variable (j). A single direct effect (unidirectional pathway) is quantitatively equal to piy while an indirect effect expressed as pjyrij of various agronomic traits on grain yield. rij is correlation between $i$ and $\mathrm{j}$ and riy piy is the indirect effect of trait $\mathrm{i}$ on $\mathrm{Y}$ via $\mathrm{j}$. For example, in the equation:

$\mathrm{r}_{1} y=\mathrm{p}_{1} y+\mathrm{r}_{12} \mathrm{p}_{2} y, \mathrm{p}_{1} y$

Where the direct effect of trait 1 on response variable (Y) (the path coefficient), while $\mathrm{r}_{12} \mathrm{p}_{2} y$ is the indirect effect of trait 1 on Y via 2.

The principal component analysis method explained by (Yan 2011) was followed in the extraction of the components. Principal Component Analysis was performed using XLSTAT 2014 software.

\section{RESULTS AND DISCUSSION}

\subsection{Means performance}

Means performance of all genotypes under normal and water stress irrigation are presented for all studied characters in Table 2. The earliest in days to heading is recorded for accession 3 and commercial cultivar Yacora with values 106.67 day and 107.33 day under normal irrigation, respectively. While Yacora gave the earliest heading with value 90 days under water deficit irrigation respectively, followed by accession 4, Sids 13 and accession 7 with values $(101.67,101.67$ and 102) at water deficit, respectively. The demonstrated clearly that there were marked differences among genotypes in heading date and varied in their response from normal to deficit treatments.

As for days to maturity, four accessions (5, 6 and 4) under normal irrigation gave the earliest mature with the lowest mean value (152.67, 152.67 and 152.83), respectively. Meanwhile, the accessions 7,8,6,5 and Sids 13 obtained the earliest mature with the lowest mean values (144.33, 145,146.33, 147.33 and 147.50 days) at water deficit irrigation, respectively. It observed that the lowest mean value for earliness if it found in wheat is favorable for escaping from disease as well as high temperature in maturity and stress conditions that have the same effect. The plant height ranked from $(80-159.83 \mathrm{~cm})$ and $(77.33-127.17 \mathrm{~cm}$ ) for each of accessions (4 and 1) under normal and deficit irrigation, respectively. According to the variation among genotypes, which will, helping the plant breeders to select for lodging resistant trait. The highest mean value for spike length ranked from $(6.17-10.33 \mathrm{~cm})$ and $(5.17-8.83 \mathrm{~cm})$ for each of acc essions (4and 12) under normal and stress irrigation, respectively. Indicate that there was a variation among genotypes studied that contributory plant-breeding program. As for number of spikes $/ \mathrm{m}^{2}$ both of accession 4 and 6 recorded the highest numbers of plant under normal and water deficit irrigation. Regarding too number of kernels /spike showed that Sids 13 and accession 3 obtained the greatest value (50.07 and 50.00) under normal irrigation on the other hand accessions 6 and 5 gave the greatest values (37.73 and 37.08) at water deficit. Meanwhile, accession 12 recorded the lowest values under normal and water deficit irrigation.

As for 100-Kernels weight four genotypes; accessions $(4,3,5)$ and Sids 13 obtained the greatest values under normal irrigation with values (6.66, 6.11, 6.07 and 6.19), respectively. On the other side, accession 11 recorded the highest values under water deficit irrigation with value $(5.93 \mathrm{gm})$ followed by accession 5 and Sids 13 . As for protein percentage, the mean values of accession 11 recorded the highest values (12.57) under normal. Meanwhile, four accessions $(6,5,12$ and 13) showed the highest values $(14.84,14.51,14.46$ and 14.15) at water deficit. It was clear that most of the protein percentage increased under water stress and that was applicable for the most genotypes studded. In addition, accessions ( 5 and 6 ) recorded the highest values for carbohydrate percentage under normal irrigation and water stress with values $(68.22,66.82)$ and $(68.27,67.12)$, respectively. As for ash percentage the accessions $(3,10$ and 13 recorded the lowest values $(0.53,0.55$ and 0.56$)$ under normal irrigation, respectively. On the other hand, the accessions 


\section{EL Shal M.H et al., 2021}

Table 2. Mean performance of wheat germplasm under normal and irrigation.

\begin{tabular}{|c|c|c|c|c|c|c|c|c|c|c|c|c|}
\hline \multirow{2}{*}{ No } & \multicolumn{3}{|c|}{ DH } & \multicolumn{2}{|c|}{ DM } & \multicolumn{2}{|c|}{$\mathbf{P H}$} & \multicolumn{2}{|c|}{ SL } & \multicolumn{3}{|c|}{ No.S/m $/ \mathrm{m}^{2}$} \\
\hline & \multicolumn{2}{|c|}{ Normal } & Stress & Normal & Stress & Normal & Stress & Normal & Stress & Normal & \multicolumn{2}{|c|}{ Stress } \\
\hline 1 & \multicolumn{2}{|c|}{118.33} & 112.00 & 164.67 & 162.50 & 159.83 & 127.17 & 7.67 & 6.33 & 364.58 & \multicolumn{2}{|c|}{347.22} \\
\hline 2 & \multicolumn{2}{|c|}{113.67} & 108.67 & 156.83 & 151.33 & 135.83 & 113.50 & 8.33 & 6.67 & 375.69 & \multicolumn{2}{|c|}{334.03} \\
\hline 3 & \multicolumn{2}{|c|}{106.67} & 105.00 & 155.83 & 150.17 & 132.17 & 108.67 & 8.83 & 6.33 & 379.17 & \multicolumn{2}{|c|}{363.19} \\
\hline 4 & \multicolumn{2}{|c|}{109.00} & 101.67 & 152.83 & 150.33 & 80.00 & 77.33 & 6.17 & 5.17 & 387.50 & & 5.28 \\
\hline 5 & & 0.33 & 107.00 & 152.67 & 147.33 & 98.67 & 91.33 & 7.17 & 6.33 & 359.03 & & 2.08 \\
\hline 6 & & 0.67 & 107.00 & 152.67 & 146.33 & 100.67 & 91.67 & 7.00 & 6.50 & 385.42 & & 9.50 \\
\hline 7 & & 2.00 & 102.00 & 153.50 & 144.33 & 92.33 & 80.33 & 8.00 & 6.67 & 370.83 & & 2.08 \\
\hline 8 & & 8.33 & 107.00 & 154.67 & 145.00 & 112.67 & 95.00 & 7.83 & 6.83 & 375.00 & & 0.69 \\
\hline 9 & & 7.00 & 110.67 & 160.67 & 154.67 & 135.83 & 115.67 & 10.00 & 8.33 & 377.78 & & 0.97 \\
\hline 10 & & 9.00 & 114.00 & 165.00 & 164.50 & 135.50 & 117.17 & 6.17 & 6.00 & 372.92 & & 3.47 \\
\hline 11 & & 9.33 & 114.33 & 165.00 & 160.17 & 151.67 & 126.00 & 9.17 & 8.50 & 383.33 & & 2.50 \\
\hline 12 & & 6.33 & 108.33 & 156.67 & 151.00 & 151.67 & 123.50 & 10.33 & 8.83 & 354.86 & & 3.06 \\
\hline 13 & & 7.33 & 111.67 & 160.83 & 157.17 & 138.00 & 107.50 & 6.67 & 6.33 & 380.22 & & 9.72 \\
\hline 14 & & 9.00 & 101.67 & 153.17 & 147.50 & 91.83 & 80.83 & 9.33 & 7.83 & 381.94 & & 3.89 \\
\hline 15 & & 7.33 & 90.00 & 156.83 & 150.67 & 99.33 & 91.83 & 8.67 & 7.67 & 370.14 & & 1.94 \\
\hline Mean & & 2.96 & 106.73 & 157.46 & 152.20 & 121.07 & 103.17 & 8.09 & 6.96 & 374.56 & & 3.98 \\
\hline L.S.D5\% & & 69 & 2.30 & 1.83 & 2.43 & 6.43 & 4.60 & 1.49 & 1.22 & 18.34 & & .37 \\
\hline & 2 & inue & & & & & & & & & & \\
\hline No. & No. & $\bar{K} / \mathrm{S}$ & & 0- KW & Prote & ein\% & Carl & $0 . \%$ & ash & & GV & \\
\hline & Normal & Stress & is Normal & al $\quad$ Stress & Normal & Stress & Normal & Stress & Normal & Stress & Normal & Stress \\
\hline 1 & 44.20 & 31.40 & 5.26 & 5.29 & 9.61 & 12.44 & 63.77 & 64.62 & 1.18 & 1.22 & 1.63 & 1.48 \\
\hline 2 & 37.73 & 30.53 & 4.97 & 5.23 & 8.12 & 11.86 & 63.77 & 64.67 & 0.70 & 1.31 & 1.33 & 1.25 \\
\hline 3 & 50.00 & 36.70 & 6.11 & 5.17 & 7.61 & 12.14 & 65.02 & 65.87 & 0.53 & 0.98 & 2.02 & 1.61 \\
\hline 4 & 47.63 & 33.13 & 6.66 & 5.09 & 10.39 & 12.14 & 67.22 & 64.62 & 0.73 & 1.41 & 2.20 & 1.24 \\
\hline 5 & 48.10 & 37.08 & 6.07 & 5.67 & 8.92 & 14.51 & 68.22 & 66.82 & 1.26 & 1.54 & 2.00 & 1.81 \\
\hline 6 & 43.80 & 37.73 & 5.99 & 5.40 & 9.70 & 14.84 & 68.27 & 67.12 & 1.37 & 1.97 & 2.01 & 1.93 \\
\hline 7 & 40.10 & 34.40 & 5.63 & 5.23 & 7.76 & 12.31 & 68.17 & 65.62 & 0.88 & 1.28 & 1.68 & 1.45 \\
\hline 8 & 42.60 & 33.23 & 5.61 & 5.31 & 6.93 & 12.41 & 64.22 & 65.37 & 0.82 & 0.89 & 2.16 & 1.59 \\
\hline 9 & 40.00 & 32.00 & 5.50 & 4.52 & 6.87 & 13.99 & 67.07 & 65.97 & 0.69 & 1.32 & 1.40 & 1.04 \\
\hline 10 & 39.87 & 36.80 & 5.48 & 5.30 & 7.55 & 12.46 & 67.62 & 64.07 & 0.55 & 1.01 & 1.71 & 1.58 \\
\hline 11 & 44.93 & 31.97 & 5.25 & 5.93 & 12.57 & 12.64 & 66.17 & 61.82 & 1.14 & 1.34 & 1.48 & 1.45 \\
\hline 12 & 35.97 & 29.27 & 4.61 & 4.79 & 8.42 & 14.46 & 64.67 & 63.77 & 0.80 & 1.22 & 1.68 & 1.29 \\
\hline 13 & 38.77 & 30.73 & 5.49 & 5.05 & 7.23 & 14.15 & 65.97 & 64.22 & 0.56 & 1.28 & 1.63 & 1.31 \\
\hline 14 & 50.07 & 35.00 & 6.19 & 5.51 & 8.65 & 13.10 & 67.02 & 63.67 & 1.19 & 1.10 & 2.35 & 1.65 \\
\hline 15 & 36.13 & 27.43 & 5.67 & 4.76 & 8.84 & 12.47 & 64.82 & 64.62 & 0.83 & 1.31 & 1.85 & 1.07 \\
\hline Mean & 42.66 & 33.16 & 5.63 & 5.22 & 8.61 & 13.06 & 66.13 & 64.81 & 0.88 & 1.28 & 1.81 & 1.45 \\
\hline L.S.D5\% & 7.12 & 8.76 & 1.05 & 0.85 & 0.22 & 0.34 & 0.62 & 0.37 & 0.09 & 0.07 & 0.39 & 0.39 \\
\hline
\end{tabular}

(8 and 3 ) showed the lowest values at water deficit. It is clear that protein percentage increased significantly with deficit compared with non-stress condition for the most genotypes. While, the carbohydrate percentage decreased significantly to deficit compared with non-stress condition, indicating that selection for stress tolerance should give a positive yield response under stress. Also, the results indicated that selection under irrigated environment would be less effective for improving grain yield under water deficit than direct selection in the stress condition, Dawwam et al., (2012) and EL-Hosary et al.,
(2012) found that there were significant increase of protein for the most genotypes, carbohydrate and ash percentage exhibited to abiotic stress. In addition, Kramer (1983) recorded that, carbohydrate and protein metabolism are disturbed under water deficit and this often leads to accumulation of sugar and amino acids.

Regarding grain weight / plot: three genotypes; commercial variety Sids 13 and accessions (4 and 8) obtained the greatest values under normal irrigation with values $(2.35 \mathrm{~kg}, 2.20 \mathrm{~kg}$ and $2.16 \mathrm{~kg})$, respectively. On the contrary, both of accessions ( 6 and 5) showed the highest 


\section{Scientific Journal of Agricultural Sciences 3 (1): 92-100, 2021}

values (1.93 and 1.81) at water stress. Atlin and Frey (1989) demonstrated that grain yield in stress or low productively environments were not controlled by same genes, making indirect selection unattractive. In addition, results indicated that the mean value of the normal environment of yield and its components was higher than with stress condition.

\subsection{Variability and genetic parameters}

The estimates of phenotypic variances $\left(\sigma^{2} \mathrm{ph}\right)$, genotypic variances $\left(\sigma^{2} \mathrm{~g}\right)$, phenotypic coefficients of variation (P.C.V), genotypic coefficients of variation (G.C.V) and broad sense heritability $\left(\mathrm{H}^{2}\right)$ given in Table 3 .
The estimates of PCV were a highly for ash percentage with values (29.88 and 24.32) followed by plant height with values (21.77 and 21.40), spike length With values (19.48 and 17.52) and grain yield per plot with values (19.68 and 21.46) under normal irrigation and water stress, respectively. Carbohydrate percentage showed a low PCV value (2.54 and 2.11) under normal and water stress irrigation, respectively. A highly GCV for plant height values (21.43 and 21.15) followed by Spike length with values (14.28 and 13.47) and grain yield per plot with values (15.31 and 14.91) under normal and water stress irrigation, respectively.

Table 3. Estimation of genetic parameters for different quantitative traits in wheat germplasm under normal and water stress irrigation.

\begin{tabular}{|c|c|c|c|c|c|c|c|c|c|c|c|}
\hline \multicolumn{12}{|c|}{ Normal irrigation } \\
\hline & $\overline{\text { DH }}$ & $\overline{\mathbf{D M}}$ & $\mathbf{P H}$ & SL & No.S/m2 & No.K/S & 100- KW & Protein\% & Carbo.\% & $\operatorname{ash} \%$ & GW/P \\
\hline$\delta^{2} \mathrm{~g}$ & 19.50 & 21.02 & 673.31 & 1.33 & 79.32 & 19.72 & 0.13 & 2.28 & 2.67 & 0.07 & 0.08 \\
\hline$\delta^{2} \mathrm{ph}$ & 23.24 & 22.39 & 694.73 & 2.48 & 108.56 & 29.16 & 0.53 & 2.30 & 2.81 & 0.07 & 0.13 \\
\hline PCV & 4.27 & 3.00 & 21.77 & 19.48 & 2.78 & 12.66 & 12.97 & 17.63 & 2.54 & 29.88 & 19.68 \\
\hline GCV & 3.91 & 2.91 & 21.43 & 14.28 & 2.38 & 10.41 & 6.48 & 17.55 & 2.47 & 29.00 & 15.31 \\
\hline $\mathbf{H}^{2}$ & 83.90 & 93.88 & 96.92 & 53.69 & 73.06 & 67.62 & 25.00 & 99.13 & 95.02 & 94.23 & 60.53 \\
\hline \multicolumn{12}{|c|}{ Water stress } \\
\hline$\delta^{2} \mathrm{~g}$ & 37.75 & 38.81 & 476.22 & 0.88 & 81.85 & 0.84 & 0.04 & 1.03 & 1.83 & 0.07 & 0.05 \\
\hline$\delta^{2} \mathrm{ph}$ & 40.50 & 41.87 & 487.20 & 1.48 & 138.83 & 26.95 & 0.30 & 1.07 & 1.88 & 0.10 & 0.10 \\
\hline PCV & 5.96 & 4.25 & 21.40 & 17.52 & 3.33 & 15.65 & 10.50 & 7.93 & 2.11 & 24.32 & 21.46 \\
\hline GCV & 5.76 & 4.09 & 21.15 & 13.47 & 2.56 & 2.77 & 3.83 & 7.78 & 2.09 & 20.20 & 14.91 \\
\hline $\mathbf{H}^{2}$ & 93.21 & 92.69 & 97.75 & 59.13 & 58.96 & 3.13 & 13.33 & 96.27 & 97.34 & 68.97 & 48.28 \\
\hline
\end{tabular}

$\delta^{2} \mathrm{~g}=$ Genotypic variance, $\delta^{2} \mathrm{ph}=$ Phenotypic variance, $\mathrm{PCV}=$ Phenotypic coefficient of variance, $\mathrm{GCV}=$ Genotypic coefficient of variance, $\mathrm{H}^{2}=$ Broad sense heritability.

Number of spikes per $\mathrm{m}^{2}$ and carbohydrate percentage showed a low GCV value (2.38 and 2.56) under normal, water stress irrigation. The PCV values were higher than GCV values for all the traits in normal and water stress irrigation. Which indicated that the association between these traits was largely under genetic control and indicated the preponderance of genetic variation in expression of traits (Tsegaye et al. 2012)? Estimates of heritability in the broad sense ranged from (25\%) for 100-kernel weight to $(99.13 \%)$ for protein percentage of normal irrigation, $3.13 \%$ for number of kernels per spike to 97.75 for plant height of water stress. Tripathi et al., (2015) reported high heritability estimates for thousand-grain weight and Yahaya (2014) for plant height. Heritability alone provides no indication of the amount of genetic improvement that would result from the selection of individual genotype. Hence, knowledge on heritability coupled with genetic advance is useful Rosmaina et al., (2016).

\subsection{Correlation analysis}

Correlation coefficients among chemical and yield component traits are presented in table 4. Data revealed that eight positive correlation coefficients observed under normal and water stress irrigation as follows; the correlation Data revealed that coefficients between days to heading each of Days to maturity, days to heading each of plant height, days to maturity each of. Plant height, number of spikes $/ \mathrm{m}^{2}$ each of 100- kernel weight, number of kernels/spike vs. 100- kernel weight, number of kernels/spike vs. Grain w eight/plot, 100- kernel weight vs. Grain weight/plot and the last positive correlation coefficient was between Protein percentage vs. Ash percentage of normal and water stress irrigation. Three correlation coefficients found at water stress; the first one was between numbers of kernels/spike each of Number of spikes $/ \mathrm{m}^{2}$. The sec ond one was between grain weight/plot each of. Number of spikes $/ \mathrm{m} 2$. The third one was between numbers of kernels/spike vs. Carbohydrate percentage. 
Table 4. Correlation coefficients between morphological and yield component traits in wheat germplasm under normal and water deficit irrigation.

\begin{tabular}{|c|c|c|c|c|c|c|c|c|c|c|c|}
\hline \multicolumn{12}{|c|}{ Normal irrigation } \\
\hline & DH & DM & $\mathbf{P H}$ & SL & No.S $/ \mathrm{m}^{2}$ & No.K/S & 100- KW & Protein \% & Carbo. \% & Ash \% & GW/P \\
\hline$\overline{\mathrm{DM}}$ & $0.83 * *$ & 1.00 & & & & & & & & & \\
\hline PH & $0.76^{* *}$ & $0.81 * *$ & 1.00 & & & & & & & & \\
\hline SL & 0.04 & 0.03 & 0.32 & 1.00 & & & & & & & \\
\hline No.S $/ \mathrm{m}^{2}$ & -0.17 & -0.06 & -0.28 & -0.24 & 1.00 & & & & & & \\
\hline No.K/S & -0.40 & -0.29 & -0.33 & -0.15 & 0.35 & 1.00 & & & & & \\
\hline 100- KW & $-0.66 * *$ & $-0.54 *$ & $-0.78 * *$ & -0.44 & $0.51 *$ & $0.73 * *$ & 1.00 & & & & \\
\hline Protein \% & 0.14 & 0.14 & 0.00 & -0.03 & 0.22 & 0.32 & 0.11 & 1.00 & & & \\
\hline Carbo\% & -0.04 & -0.28 & $-0.55^{*}$ & -0.34 & 0.24 & 0.30 & 0.53 & 0.10 & 1.00 & & \\
\hline Ash \% & -0.07 & -0.22 & -0.22 & 0.03 & -0.08 & 0.38 & 0.15 & $0.58 *$ & 0.27 & 1.00 & \\
\hline GW/P & $-0.75 * *$ & $-0.65^{*}=$ & $*-0.70 * *$ & -0.25 & $\begin{array}{l}0.21 \\
\text { Water }\end{array}$ & $\begin{array}{l}0.64 * * \\
\text { r deficit }\end{array}$ & $0.77 * *$ & 0.02 & 0.25 & 0.26 & 1.00 \\
\hline DM & $0.60 *$ & 1.00 & & & & & & & & & \\
\hline icit PH & $0.72 * *$ & $0.81 * *$ & 1.00 & & & & & & & & \\
\hline SL & 0.01 & 0.01 & 0.29 & 1.00 & & & & & & & \\
\hline No.S/m² & -0.07 & -0.17 & -0.34 & -0.18 & 1.00 & & & & & & \\
\hline No.K/S & 0.21 & -0.20 & -0.25 & -0.45 & $0.62 *$ & 1.00 & & & & & \\
\hline 100- KW & 0.30 & 0.03 & -0.03 & -0.17 & $0.59 *$ & $0.51 *$ & 1.00 & & & & \\
\hline Protein \% & 0.20 & -0.14 & -0.01 & 0.29 & 0.32 & 0.15 & -0.10 & 1.00 & & & \\
\hline Carbo\% & -0.11 & $-0.52 *$ & -0.36 & -0.42 & 0.14 & $0.54^{*}$ & -0.15 & 0.34 & 1.00 & & \\
\hline Ash \% & -0.06 & -0.21 & -0.24 & -0.08 & 0.29 & 0.15 & 0.12 & $0.56^{*}$ & 0.38 & 1.00 & \\
\hline GW/P & 0.21 & -0.23 & -0.18 & -0.31 & $0.72 * *$ & $0.83 * *$ & $0.72 * *$ & 0.26 & 0.39 & 0.21 & 1.00 \\
\hline
\end{tabular}

\footnotetext{
$*$ ** Signific ant at 0.05 and 0.01 probability levels, respectively.
}

Nevertheless, there were four negative correlation coefficients between 100-kernel weight and plant height and grain weight/plot and plant height under normal irrigation. As well as the association negative correlation between carbohydrate percentage and plant height and grain weight/plot with days to heading under normal irrigation. These results are agreed with Khaliq et al. (2004) and (Nayeem and Baig 2003). (Garcia del Moral et al, 2005) found that the correlation coefficient measures the relationship between two characters and does not indicate the relative importance of each factor. Correlation coefficients show relationships among independent variables. However, it is not sufficient to describe this relationship when the causal relationship among variables is needed (Korkut and Bilir 1993). (Mahdi et al, 2017) showed that grain yield had the highest correlation with harvest index under all conditions, indicating importance of harvest index to improve grain yield.

\subsection{Path coefficient analysis}

Path coefficient analysis for traits studied of wheat genotypes on the grain yield / plant under normal and water deficit irrigation are presented in table 5. The direct contribution of 100- kernel weight to grain yield was highest $(0.78)$ under normal irrigation followed by number of kernels per spike at water deficit (0.54). Number of kernels per spike also had an appreciable indirect effect via a number of spikes per $\mathrm{m} 2$ at water deficit (0.34) followed by 100 - kernel weight of water deficit $(0.28)$. 100- Kernel weight had the highest indirect effect an appreciable indirect effect via a number of kernels per spike under normal irrigation $(0.57)$ follow ed by a number of spikes per $\mathrm{m} 2$ under normal irrigation (0.40). The residual effect was 0.36 and 0.18 under normal and water 
Scientific Journal of Agricultural Sciences 3 (1): 92-100, 2021

Table 5. Path coefficients of grain yield and its related characters in wheat genotypes under normal and water deficit irrigation.

\begin{tabular}{|c|c|c|c|c|}
\hline \multicolumn{5}{|c|}{ Normal irrigation } \\
\hline \multirow{2}{*}{ Character } & \multirow{2}{*}{ Direct effect } & \multicolumn{3}{|c|}{ Indirect effect } \\
\hline & & No.S $/ \mathrm{m}^{2}$ & No.K/S & 100- KW \\
\hline No.S $/ \mathrm{m}^{2}$ & -0.24 & & 0.06 & 0.40 \\
\hline No.K/S & 0.16 & -0.09 & & 0.57 \\
\hline 100- KW & 0.78 & -0.13 & 0.12 & \\
\hline \multicolumn{5}{|c|}{ Residual effect $=0.36$} \\
\hline \multicolumn{5}{|c|}{ Water deficit } \\
\hline No.S $/ \mathbf{m}^{2}$ & 0.18 & & 0.34 & 0.20 \\
\hline No.K/S & 0.54 & 0.11 & & 0.17 \\
\hline 100- KW & 0.34 & 0.10 & 0.28 & \\
\hline Residual ef & & & & \\
\hline
\end{tabular}

deficit irrigation, respectively, which indicated that some more other traits were responsible for contributing to grain yield but not taken into consideration in the present investigation. The path coefficient analysis appeared as a clue to the contribution of various yield components for grain yield in the genotypes under the study. It provides an effective way of finding out direct and indirect sources of correlation. These results agree with El Shal (2016), Okuyama et al. 2004) found that the grain yield is a complex trait which is influenced by many factors, and plant breeders are interested to know the nature of the relationship and the kind of correlation among traits.

\subsection{Principal component analysis}

Principal component analysis shows the significance of the major contributor to the total variation in each dimension of differentiation. The eigenvalues help to identify the number of factors to be retained table 6 . The results showed that the first two components explained (40.62 and $18.20 \%)$ and $(32.42 \%$ and $22.41 \%$ ) under normal irrigation and water stress of the total variation. The first component (PC1) mostly was affected dellete by a positive and negative coefficient with values 0.93 for 100-kernel weight and -0.90 for plant height under normal irrigation, plant height and days to maturity with, positive coefficient at water stress.

Table 6. Loadings of PCA for the estimated traits of wheat genotypes under normal and water deficit irrigation.

\begin{tabular}{ccccc}
\hline & \multicolumn{2}{c}{ Normal irrigation } & \multicolumn{2}{c}{ Water stress } \\
\hline & PCA 1 & PCA2 & PCA 1 & PCA2 \\
\hline DH & -0.75 & 0.48 & 0.39 & 0.79 \\
DM & -0.75 & 0.45 & 0.72 & 0.52 \\
PH & -0.90 & 0.24 & 0.78 & 0.47 \\
SL & -0.37 & -0.14 & 0.42 & -0.20 \\
No.S/m & 0.45 & 0.25 & -0.63 & 0.48 \\
No.K/S & 0.67 & 0.37 & -0.66 & 0.58 \\
100- KW & 0.93 & 0.03 & -0.26 & 0.68 \\
Protein \% & 0.15 & 0.83 & -0.32 & 0.20 \\
Carbohydrate\% & 0.58 & 0.25 & -0.71 & -0.04 \\
Ash \% & 0.33 & 0.59 & -0.52 & 0.13 \\
Eigenvalue & 4.06 & 1.82 & 3.24 & 2.24 \\
\% variance & 40.62 & 18.20 & 32.42 & 22.41 \\
Cumulative \% & 40.62 & 58.82 & 32.42 & 54.84 \\
\hline
\end{tabular}

The most effective indices in the second component (PC2) were protein and ash percentages with positive coefficients under normal irrigation, days to heading and 100-kernel weight with positive coefficients at water deficit. Mohammed and Kadhem (2017) showed that PCA were significantly inter-correlated with each other indicating that several of the statistics probably measure similar aspects of drought tolerance. Naghavi, et al., 
(2015)and Naghavi and Khalili (2017)showed that used factor analysis to identify growth and morphological characters relevant to yield in wheat and introduced factors which included yield components, morphological characters, spike length and the number of grain per plant. Also, factor analysis under normal and drought stress, yield components factor with description of high amount from total variation was common that it showed importance of related traits to it.

\section{REFERENCES}

Abraha MT, Hussein S, Laing M, Assefa K (2017). Early generation genetic variation and heritability of yield and related traits among tef populations. J. Crop Sci. Biotechnol.20: 379-386.

Ali MA, Nawab NN, Abbas A, Zulkiffal M, Sajjad M (2009). Evaluation of selection criteria in Cicer arietinum L. using correlation coefficients and path analysis. Australian J. Crop Sci. 3(2): 65-70.

Atlin GN, Fery KJ (1989). Breeding the relative effectiveness of direct versus indirect selection for at yield in three types of stress environments. Euphytica, 44: 137142.

Aydin N, Ermet C, Mut Z, Bayramo HO, Özcan H (2010). Path analyses of yield and some agronomic and quality traits of bread wheat (Triticum aestivum L.) under different environments. Afric. J. Biotech.9 (32): 5131 5134.

Dawwam HA, Hendawy FA, Zanaty AM, Mustafa AK, Arab SA (2012). Characterization and evaluation of some wheat genotypes under different environmental conditions 2- Graphical analysis. Minufiya J. Agric.Res., 4 (1): 881 897.

EL-Hosary AA, EL-Badawy M, Mustafa AK, El-Shal MH (2012). Breeding bread wheat for tolerance to drought stress. Minufiya. J. Agric. Res. 37 ( 2):351-369. El-Shal MH (2016). Correlation and path coefficient analyses in durum wheat genotypes. Egypt. J. Plant Breed.20 (4):1 -11.

Garcia del Moral LF, Rharrabti Y, Elhani S, Martos V, Royo C (2005). Yield formation in Mediterranean durum wheat under two contrasting water regimes based on pathcoefficient analysis. Euphytica, 146, p. 203-212.

Gulmezoglu N, Alpu O, Ozer E (2010). Comparative performance of triticale and wheat grains by using path analysis. Bulg. J. Agric. Sci., 16: 443-453.

Khaliq I, Parveen N, Chowdhry MA (2004). Correlation and path coefficient analyses in bread wheat. Int. J. Agri. Biol., 6(4):633-635.
Korkut ZKI, Bilir S (1993). The studies of path coefficient and correlation of durum wheat. Symposium of durum wheat and its products, Ankara, p, 183-187.

Kramer PJ (1983). Water relations of plants. Academic press, Inc. California, pp.16.

Kwame WSh, Shimelis H, Tapera1 T, Tsilo TJ (2019). Genetic advancement of newly developed wheat populations under drought-stressed and non-stressed conditions. J. Crop Sci. Biotech. 22 (2): 169 - 176.

Mahdi Z, Shokrpour M, Nejad SH (2017). Correlation and path coefficient analysis in wheat (Triticum aestivum L.) under various drought stress conditions. Bangladesh J. Bot. 46(4): 1309-1315.

Mitra j (2001). Genetics and genetic improvement of resistance in crop plants. Curr. Sci., 80: 758-762.

Mohammed AK, Kadhem FA (2017). Screening drought tolerance in bread wheat genotypes (Triticum aestivum L.) using drought indices and multivariate analysis Iraqi $\mathrm{J}$. of Agric. Sci. 48: 41-51.

Naghavi MR, Marouf K (2017). Evaluation of genetic diversity and traits relations in wheat cultivars under drought stress using advanced statistical methods. Acta agriculturae Slovenica 109(2):403-415.

Naghavi MR, Toorchi M, Moghaddam M, Shakiba MR (2015). Evaluation of diversity and traits correlation in spring wheat cultivars under drought stress. Notulae Scientia Biologicae, 7(3), 349-354.

Nayeem KA, Baig KS (2003). Correlation studies in durum wheat. J.Res. Angrau., 31: 116-21.

Okuyama LA, Federizzi LC, Neto JFB (2004). Correlation and path analysis of yield and its components and plant traits in wheat. Cienc. Rural. 34(6): 1701-1708. Rosmaina, Syafrudin, Hasrol, Yanti F, Juliyanti, Zulfahmi (2016). Estimation of variability, heritability and genetic advance among local chili pepper genotypes cultivated in peat lands. Bulg. J. Agric. Sci., 22: 431-436. Roy D (2000). Plant breeding analysis and exploitation of variation. Alpha Science. pp. 798.

Snedecor GW, Cochran WG (1967). Statistical Methods. 6th ed. The Iowa State University Press, Ames, IA .

Sohail A, Rahman H, Ullah F, Shah SM, Burni T, Ali S (2018). Evaluation of F4 bread wheat (Triticum aestivum l.) genotypes for genetic variability, heritability, genetic advance and correlation studies. J. Plant Breed. Genet. 6. $1-7$.

Steel RGD, Torrie JH, Dicky DA (1997) Principles and Procedures of Statistics, A Biometrical Approach. 3rd Edition, McGraw Hill, Inc. Book Co., New York, 352358. 
Tripathi GP, parde NS, Zate DK, Lal GM (2015). Genetic variability and heritability studies on bread wheat (Triticum aestivum L.). Inter.j. of Pl. Sci. 10(1):57-59.

Tsegaye D, Dessalegn T, Dessalegn Y, Share G (2012). Genetic variability, correlation and path analysis in durum wheat germplasm (Triticum durum Desf). Agri. Res. and Rev. 1(4):107-112.

XLSTAT [computer program]. Version 2014.1.01, copyright Add in soft 1995-2014.

Yahaya Y (2014). Estimate of genetic variability and correlation coefficients for some quantitative characters in bread wheat (Triticum aestivum L.) World J. of Agri. Sci. 2(7):163-167.

Yan W (2011). GGE Biplot vs. AMMI graphs for genotypes $\mathrm{X}$ environments data analysis. J.Indian Soc. Agic.Stat., 65 (2) : $181-193$.

Zhao CH, Liu L, Wang G, Huang W, Song X, Li C (2004). Predicting grain protein content of winter wheat using remote sensing based on nitrogen status and water stress. Inter.J. of Appl. Earth Observ. \& Geoinform. 7(1): $1-9$.

\title{
الملخص العريجي
}

\section{تقييم بعض التراكيب الوراثية من القمح للتحمل للحرمان المائي باستخدام بعض الصفات الزراعية والمحصولية والكميائية}

\author{
محمد حلمي الثال ' - سليمان عبدالمعبود عرب' - شريف ثابت عيسي' \\ 'البنك القومي للجينات والموارد الوراثية- مركز البحوث الزراعية - الجيزة، بَّم بحوث القمح - معهد بحوث المحاصيل الحقلية- مركز البحوث الزراعية- \\ الجيزة-مصر بـرن
}

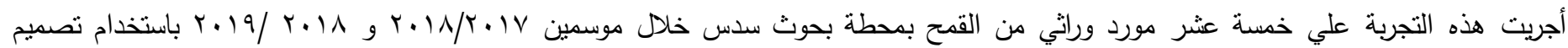

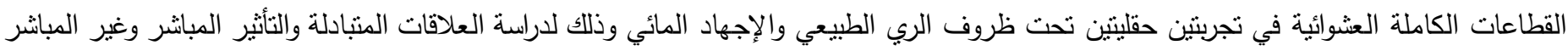

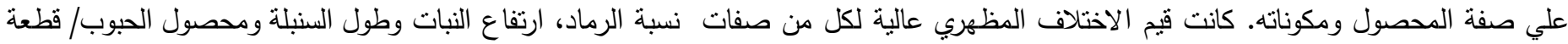

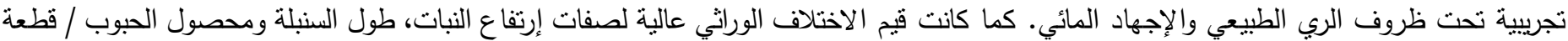

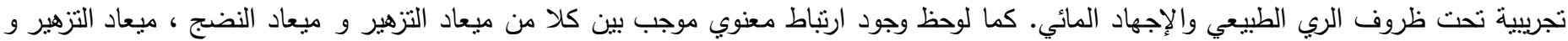

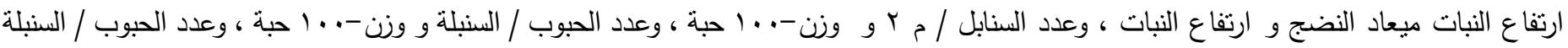

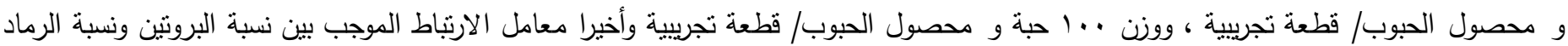

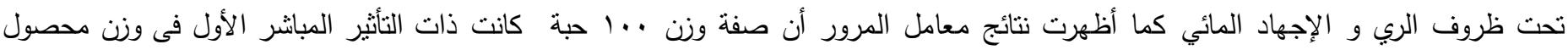

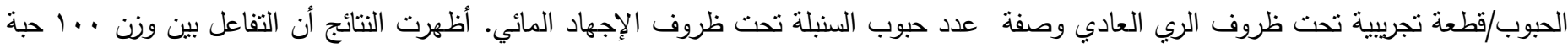

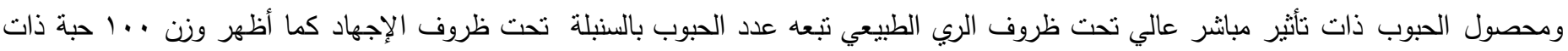

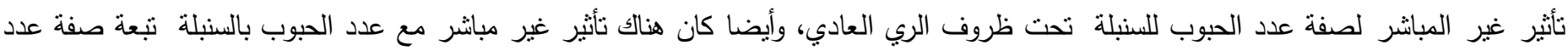

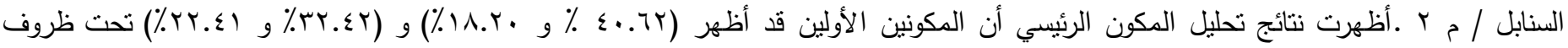
الري العادي و الإجهاد المائي على التوالي من النتاين الكلي. 